\title{
幼児聴力検査の信頼性と適応年齢
}

\author{
一 3 力年の統計からみて—
}

愛知県総合保健センター聴力音声言語診断部
板倉 秀, 浅野 進, 中川 啓子.

\section{I はじ.めに}

幼児聴力検查は，乳幼児の聴力障害の早期発見と， 聴力障害の程度, 原因疾患の診断飞必要なことは言う まであない。わが国に招いて総合的にこの研究が行わ れたのは, 名古屋大学後藤修二教授を代表として, 1962 1963年に12校の大学が参加して行われ，その結 果は, Audiometric Tests of Young Children (1963) の中にまとめて発表されている。それに引続いて，信 州大学鈴木篤郎教授を代表として，「幼坚難聴の早期 発見と教育的治療の決定に関する研究」といろ課題 で, 幼児聴力検查法のみでなく, 幼児聴力障 害の原 因, 聴力障害と言語発達, 教育的治療の適性, 聴力障 害児への補聴器装用などを含む, 幼児聴力障害のもつ 種々の問題全般にわたって研究が進められて,その結 果は,「幼児難聴の研究」日本耳鼻咽喉科学会会報,
補冊 5 （1969）飞まとめて発表されている。その後幼 児聴力検查は病院はもとより, 聴力障害児の教育施設 飞招いても積極的に行われるようとなってきた。聴力 障害についての早期診断と共飞, 治療効果の期待でき るものには医学的治療, 指導教育面での聴能言語訓練 の適用も早く決定しなくてはならない。そこで当施設 も発足して 4 力年飞達し， 聴力検查の件数もかなりの. 数になったので, それらの結果を検討, 報告すること とした。

\section{II 検査の方法とその他の条件}

検查は聴力障害招よび言語障害を主訴として当所爪 来所した者のうち，わずかでも聴力障害を疑われるす べてのものルついて夷施した。検查者は, 言語, 聴 力, 心理検査括よび言語治療訓練, 聴能訓練を担当し ている職員ですすでル 4 力年の経験をむち熟練した者

RP-02 ブロックダイブラム

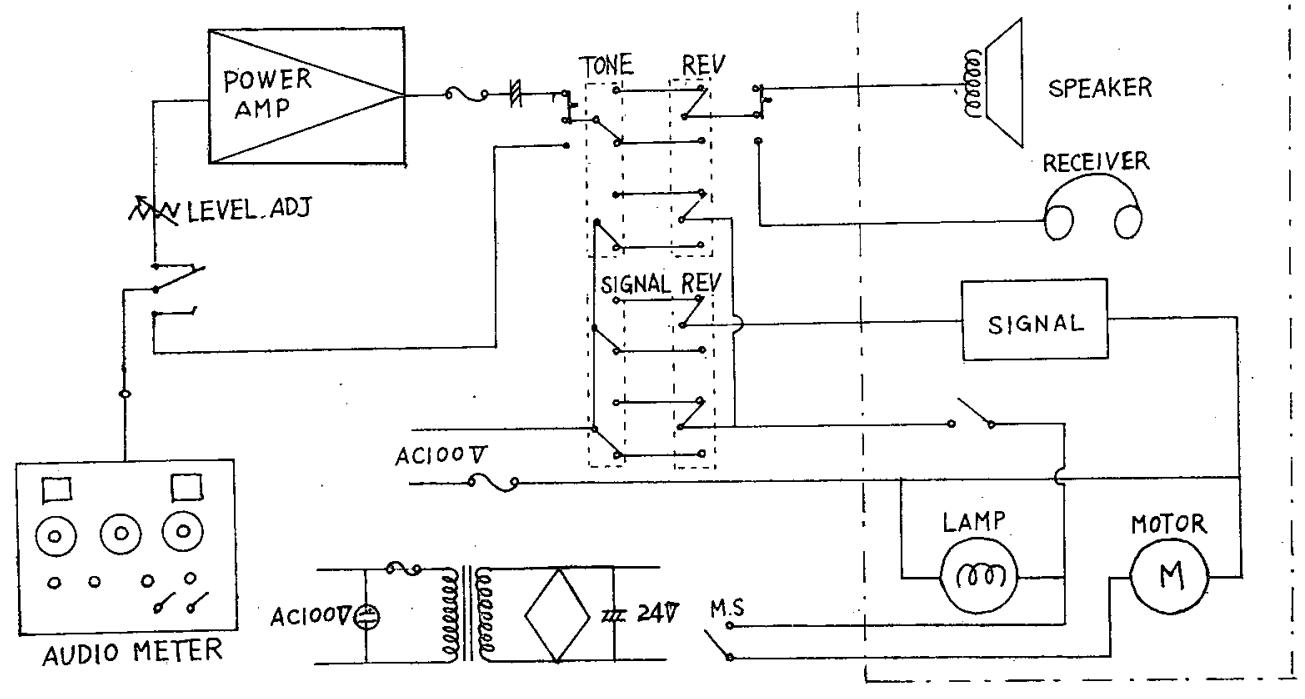

図 1 
が施行した。

検查室の一つは成人用精密検查防音室で，信大式卓 上幼児聴力検查装置を改良したものを用いて，C.O.R. test, peep show test を行い, 今一つは幼児聴力検查 專用の防音室で，広さ， $5 \times 4 \times 2.5 \mathrm{~m}$, C.O.R. test 呿よび startle response test 标隣接副室 $5 \times 1 \times 2.5 \mathrm{~m}$ の広さでマジックミラーウインドによって測定観察で きるようにした。 peep show test は防音室内で図 1 のごとき装置を試作して，オージオメ一タからの検查 音は，スピーカとレシーバとすぐ切替がでさ，さら 飞補聴器装用の聴力検查も可能なよう飞, 音圧更正, 音圧換算が比較的容易飞できるようにして検查を行っ た。

検查者は，気導招よび骨導（できる限り測定した） 飞打いて, $500 \mathrm{~Hz}, 1,000 \mathrm{~Hz}, 2,000 \mathrm{~Hz}, 4,000 \mathrm{~Hz}$, を求め, 検查值は一度の検查て得られた值が 2 回以上 $10 \mathrm{~dB}$ 以内の誤差で一致する時点で域值とした。聴力 検查は, 標準聴力検查, C.O.R. test, startle response test, peep show testを用いたが， startle response test は C.O.R. test と同時江行って拈り，一応施行 件数も C.O.R. test とほとんぞ同じであるので，統 計からは除くこととした。

\section{III 検 查 成 績}

昭和 46 年 4 月より, 塯和 49 年 3 月までの 3 年關の総 受診者 2,947 名中, 幼児聴力検查を施行した 1,214 名

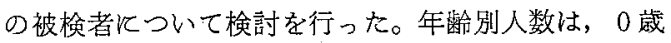
13名, 1 藏 100名, 2 藏 257名, 3 歳 222名；4 歳 154 名, 5 歳 136 名, 6 歳以上 332 名である。検査別件数 は, peep show test 3,395 件, C.O.R. test 462 件, EEG 㥁力㭘查扰よび E.R.A. 70件であった。被検者 1,214 名の中で，検查の結果, 聴力障害と診断された むのは 813 名 (67\%), 聴力正常之診断されたものは 371 名 (30.5\%), 他の 30名 (2.5\%) 杜聴力障害の疑

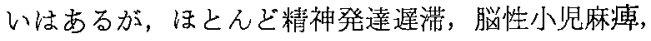
脳水腫等の重度の他疾患を合併して, 域值の決定が困 難であったあのである。

聴力障害のあるあのの中，域值決定のできたもの 讨，スピーカ法によるもの 691 名 (85\%)，さらにレシ 一バ法汇より片耳域値の決定できたもの575名(71\%), その他 37 名 (5\%) 惐值追跡中，また85名 (10\%) は域值が決定できないまま来所しなくなったあのであ る。聴力正常と診断されたうち，346名 (96.27\%) は 初診時飞一回の検查で決定され，25名は二回以上の検
查で正常恥力であることが決定されている。

1）初晾時飞括ける peep show test, C.O.R. test の 年齢別被検者数（図 2)

初診時飞招いて, C.O.R. test は peep show test の条件付けができなかったあのについて施行された。 初診時 peep show test の条件付けができたものは 868名(全体の71.5\%)であり，3 歳台飞扮いては163名 （3 歳台飞括ける73.5\%)，4歳台は139名 (90.3\%), 5 歳台128名 $(94.5 \%), 1$ 葴未満では peep show test は团難で，1歳台は11名(11\%)，2歳台104名(40.5\%) という結果を得ている。

次いで,C.O.R. test では，2歳台153名(59.5\%)， $0 \sim 1$ 歳台102名 (90\%)，3歳台59名 (26.5\%)，4歳 台15名 $(9.7 \%) ， 5$ 歳台 8 名 $(5.8 \%)$ である。

ここで C.O.R. test と peep show test $の$ 年龄別 被検者数を比較すると，図 2 飞示すごとく，C.O.R. test は 1 墄半からその数は増加して，2 歳前半で最も 多く，それ以後年龄沉しだい急汇減少している。 peep show test 牥それより約 1 年遅れて， 3 歳前半 そそのピークがありその後はC.O.R. test と異ってす こしずつその数は減少している。これは恥力障害, 言 語障害を主訴として来所する年齢層は $2 \sim 3$ 藏頃が最 あ多く, 次第に 4 歳, 5 歳と減少していることを示し ている。

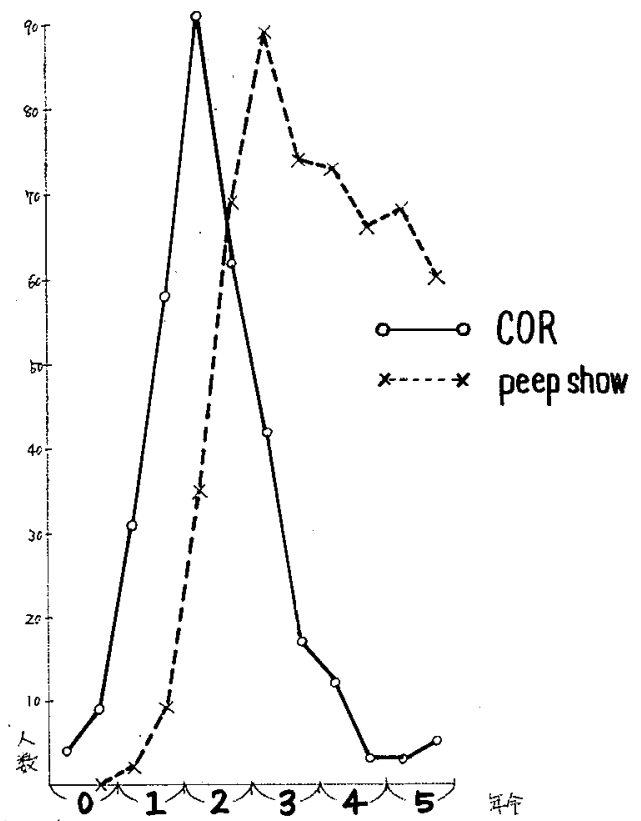

図 2 初回時飞拈ける peep show, COR 年龄別被検者数 
2）初彰時飞招ける各検查法別の割合

初診時飞扣ける，C.O.R. test と peep show test の割合をみると総被検者 1,214 名の内 868 名 $(71.5 \%)$ は peep.show test が可能で, C.O.R. test を行った あのは 346 名 $(28.5 \%)$ である。

レシーバ法により域值の決定した 691 名の中, 初検 時飞 peep show test の可能であったものは 608 名 (88\%) で，C.O.R. test Kよるあのは.83名 (12\%) で あった。初検時飞聴力正常と判定された 346 名中 153 名 (44.2\%) は C.O.R. test で決定され，193名(55.8\%) は peep show test で聴力正常であることが決定され ている。このことは，6歳未満の幼児は，聴力正常の 場合，C.O.R. test で相当数決められるが，聴力障害 があっても peep show test によって88\%も域值の確 定できていることは注目すべきである。

3）域值決定時の年齢別被検者数（図 3)

聴力障害のあるもののうち, peep show test によ って域值の決定が初回にできたもの，初回にできなか ったもの，“拉よびその後の再来炕っってできたのと 三つに分けて図表にしたものが図 3 である。スピーカ 法により域值を決定したものと、レシーバ法により域 值を決定したものを比較してみると，初回に挌ける域
值決定は 3 歳未満では少なく, スピー力法では 3 藏よ りレシーバ法では 4 歳半より, 域值の決定が初回にで きたあのが，急激潧加している。

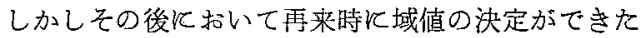
あのについてみると, 域值の決定率がかなり良好であ

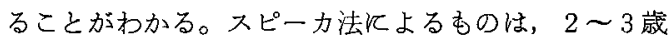
になればその数も急增加し，3〜 5 藏で少し減少し ている。この隇少は 3〜 5歳台では初回飞域值の決定 が可能であるむのが多いためであり，その年㱓台では 受診するものが減っているためである。一方レシーバ 法では年柃飞応じて，域值決定のできた数は漸次增加 している。 peep show test での域值決定は，2歳未 満ではむつかしいが，2歳半をこせば域值測定は充分

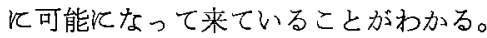

4）域值決定までの年齢別の検査期間と回数（図 4)

域值決定までの期間は，検査間の日数間隔沉よって 多少变ってくるが，その間隔で近いものは 1 ～週， 長いむのは 2 ～ 3 力月の間隔を括いて検查している。 それらを考虑に入れて，検査に要した期間で一番長い あのを，初診時の年令についてみると，スピーカ法て は，1藏台 25 力月， 2 藏台 28 力月， 3 歳台 23 力月，4 歳台 22 力, 5 歳台13力月であり, レシーバ法では,

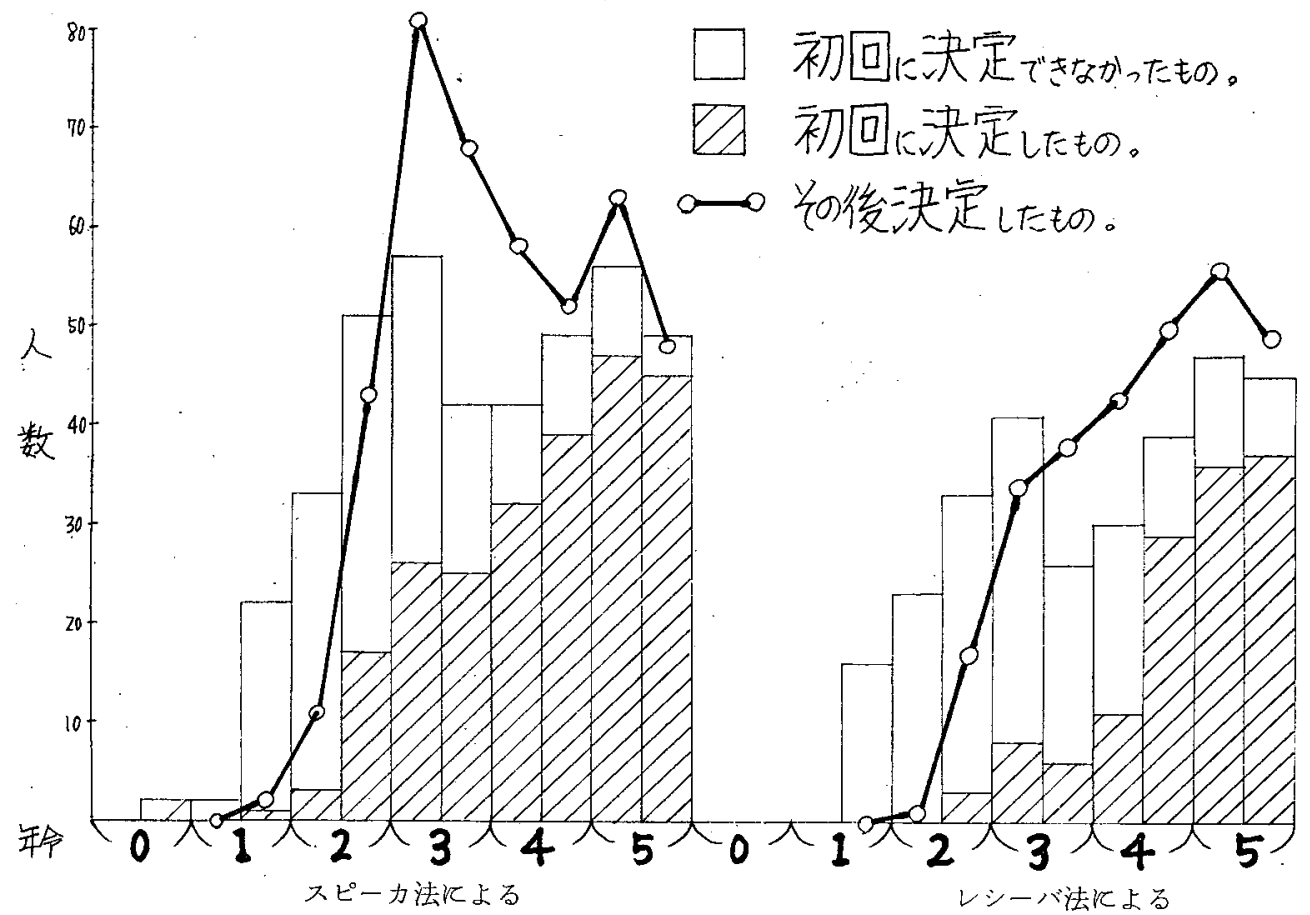

図 3 域值決定時年齢別人数 
1 歳台33力月, 2 藏台30力月, 3 藏台31力月, 4 歳台 22力月， 5 歳台 22 力月であった。両方法共飞大きな差 はなく、レシーバ法の期間が，やや長い程度である。

そこで peep show test そよる域值決定までの検查 回数を年龄別々みると，図4のごとくである。1歳末 満の 2 例は 4 回で域值決定がやっとできている。1歳

図 4 域值決定までの年齢別検査回数 (peep show)

\begin{tabular}{|c|c|c|c|c|c|c|c|c|c|c|}
\hline $\begin{array}{c}6 \\
{ }^{6} \text { 上 }\end{array}$ & & 2 & 13 & 15 & 8 & 3 & 4 & & & \\
\hline 5 & & & & 4 & 1 & 2 & 2 & 1 & 1 & \\
\hline 4 & 2 & 1 & 2 & 5 & 6 & 7 & 4 & 2 & 1 & 2 \\
\hline 3 & & 1 & 1 & 6 & 6 & 6 & 2 & & 2 & 4 \\
\hline 2 & & & 3 & 2 & 9 & 17 & 5 & 7 & 6 & 17 \\
\hline 1 & & & 1 & 2 & 17 & 23 & 25 & 32 & 39 & 368 \\
\hline 回数 & $\sim_{\curlyvee}^{11}$ & $\begin{array}{l}\text { 1歲 } \\
\underset{1.5}{\text { T.5 }}\end{array}$ & $\underset{1.11}{1.6}$ & $\begin{array}{l}2 \\
2.5\end{array}$ & $\stackrel{2.6}{2.11}$ & & 3.6 & & $\frac{4.6}{\sim .11}$ & $\mid \begin{array}{l}5 \text { 歳 } \\
\text { 上上 }\end{array}$ \\
\hline
\end{tabular}

※1歳〜2.5 歳までの被検者には検查回数が多く必 要であり，2.6 歲以上の被検者は 1 ～ 2 回での検 查によって域値決定が可能であることを太字によ って示している。

台の24例中15例は 6 回以上, 残りの 9 例は $2 \sim 4$ 回で

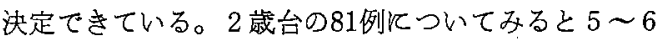
回以上が28例とかなりあり，1〜2回のものが30例， $3 \sim 4$ 回のもの24例である。3 歳台では， 1 回で可能 であったものは 100 例中 48 例， 2 回22例でその半数以 上は，1〜2回で域值决定ができている。5〜6回を 要したものは11例となっている。4 歳台では，91例中 84 例は 1 〜 回で決定でき，5歳以上では 391 例中 2 回以上要したのはわずか23例である。

以上の結果は peep show test は 3 歳未満の場合 4 〜 回位で域值測定は可能であるが，3歳を越せば， 1〜2 回の検查て域值決定ができる例が急兽すこと を示し，4〜 5 回も要するものは少なくなることがわ かる。

5）聴力障害の程度による，年齢別域值決定の割合

(図 5)

聴力の程度を, 柽度( $30 \mathrm{~dB})$, 中等度 (30 60dB), 高度 $(60 \sim 90 \mathrm{~dB}), \quad$ 万 $(90 \mathrm{~dB} \sim)$ と 4 段階に分け て, 初回惐值決定ができたものと，その後の再来で 決定できたすのについて年龄別にグラフにすると図 $\mathbf{5}$ のごとくになる。軽度の聴力障害の場合はいずれの年 齿む初回で域值の決定がほとんどできている。それと 此較すると中等度以上の聴力障害のあるものは，4 歳 までは特泳回で決定できる例が少なくなっで招り，
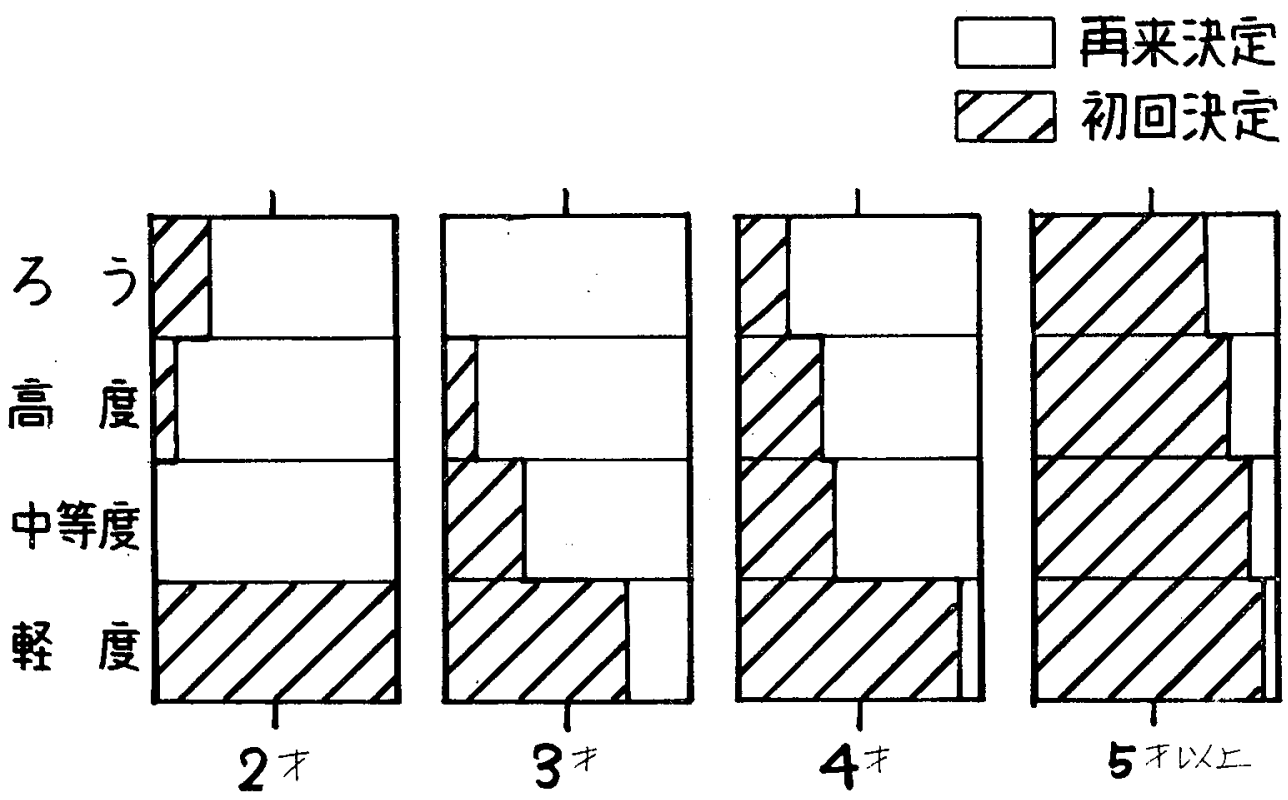

図 5 聴力障害の程度による年齢別域値決定の割合

(レシーバ法による) 
中等度聴力障害では，3歳 (33.3\%)，4歳 (40\%) で あり, 高度坓力障害では, 3 歳(13.3\%)，4藏( $35.3 \%)$ で，ろろでは, 3 歳( $0 \%), 4$ 歳 $(21 \%), 5$ 歳 $(70.3 \%)$ と, 聴力損失の大きいほど初回の域值決定率は低下し ている。しかし年秢的飞は，年齢が增加するほど初回 の決定数は增加して，5歳に達すればかなりの域值決 定が可能となってきている。このことは，中等度以上 の聴力障害がある場合は音飞対する反応も弱く，ちょ ろど正常児江执いては言語を習得してゆく時期である ため，多少なりとも精神発達遅滞をともなうことが予 想され，その影㗽がこのような結果をもたらしたとも 考光られる。

\section{IV 考察}

幼児聴力検查法と適応年齢との関係は従来の報告か b, その可能性を総合してみると, $0 \sim 6$ 力月, 強大 音代対する無条件反射の反忘を指標とする startle or orientation response とよる聴覚検査, 扣よび startle response Kよる域値検查, $1 \sim 2$ 歳; スピーカ法に よる C.O.R. test, startle response test, 3 藏; スピ 一カ法, レシーバ法による C.O.R. test, play audiometry, peep show test, $4 \sim 5$ 歳; play audiometry, standard audiometry というよに考只られている。し 玑し play audiometry, peep show test もとの装置, 方法化上って差がある。施行可能な成功率は，C.O.R.

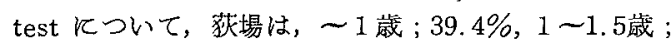
$79.4 \%, 1.6 \sim 1.11$ 歳; $86.8 \%, 2 \sim 2.5$ 歳; $81.6 \%$, 2.6〜2.11歳；91.9\%，3〜歳； $64 \%$ と報告している。 また peep show test そついては Satten とよれは， 2 歳; $43 \%, 3$ 葴; $80 \%, 4$ 歳; $93 \%, 5$ 歳; $90 \%$ と 報告している。そのほか服部 (1957), 花岡 (1957), 石沢(1960)，等の報告があるが，その結果汇大きな差 はないようである。今回の結果はこれらの結果比較 すると, C.O.R. test, peep show test 共飞, 低年秢 の成功率が従来よりあ有効であり，検查の対象年齢も 低下している。このことは，検査装置の改良飞加え て, 検查者の幼児聴力検查法への習熟と経験が，平均 して良好な結果をあたらした一つの要素沉すなっい ると考光られる。

次従来検查ができなかったものの，その後の再検 査の成績の報告は少ない。その結果をみると, 両方法 共飞年令の增加に徉ってその域值決定は容易になって いることは当然である。4〜 5歳では初回でほとんど 域值の決定が可能であり，4歳で 3 回以上， 5 歳で 2
回以上で決定されたものは重複障害であったものが多 い。また 3 歳未満での peep show test の可能な割合 が低いことは，従来の報告の共通の意見であるが， あ る程度回数を重ねることによって，域值の決定が可能 であることあまた注目すべき結果であった。

1）精神発達遅滞, C P 等の障害の上飞, 聴力障害 の重複障害が疑われる者についても，聴力障害の有無 の早期診断飞, C.O.R. test のはたす役割は大きい。

2）聴力障害児の域值決定飞ついては, peep show test の信頼度はかなり高い。

3） peep show test Kよる早期域値決定飞は，対 象児の年齢（が低いほど），聴力障害の程度（の重い むのほど）飞大きく左右される。

4） peep show test Kよるスピーカ法域値決定は, 早期検查の開始，さらに期間と回数をかけて追跡する ことによって，2歳台炕可能である。ただし検查間隔 は，個人差はあ万弓が，条件付けができるまでは頻回 そ抗こなってもよいが，できたあとは，半月，あるい は 1 力年飞 1 回程度が適当と思われる。

5）スピーカ法による域值は大まかな域値, 聴力型 を知る上でレシーバ法への readiness として意味を 持っている。その上でのレシーバ法による域值は成人 の精密聴検汇近い意味を持つ。

6）恥力障害児の早期域値決定は，その程度の悪い 注ど反応が不安定であるので，域值決定は慎重を要す る。

今後われわれの課題として, peep show test の装 置利用による骨導域值も加えて, 幼児の聴力障害部位 のより適確な診断法を確立したいと考光ている。

\section{The Reliability and Applicable Age of Audiometric Test of Young Children}

by

Shigeru Itakura, Susumu Asano, and Keiko Nakagawa

Dept. of Hearing and Speech Clinic, Aichi Prefectural Center of Health Care

With regard to play audiometry (C.O.R.-test, and peepshow test) the procedure, applicable age, reliability and threshold of children who consult to this center from 1972 to 1974 , were studied and the following results were obtained.

1) Applicable age for C.O.R. test to measure the threshold was from 1.5 to 3 years of age, and that 
for peepshow test was above 2.5 years of age.

2) In the cases the threshold was not measured at first time in children under 2 years old, by repeating test the threshold was mostly decided by peepshow test.

3) As the threshold of hearing impaired children were unreliable by only one test, they should undergo the careful measurement of threshold by repeated tests.

\section{文献}

1) Goto, S.: Audiometric tests of young children. p. 4 32, 丸善名古屋支店, 1964 .

2）荻場芳雄：3才末満の幼児に対する純音聴力測定 法一条件栓索反射德力測定 C.O.R. Audiometry 飞 ついて一. 耳喉, 32; 809, 1960.
3) 荻場芳雄: 条件栓索反射聴力測定法に上る乳幼児 の正常聴力について. Audiology Japan, 4；24, 1961.

4) 石沢博子: Play Audiometry 炕関する研究. 耳鼻 と臨床，6；397，1960.

5）武居哲也：条件栓索反射聴力測定 C.O.R. Audio-

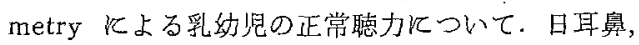
$66 ; 1366,1963$.

6）鈴木篤郎：幼児難聴の研究. 日耳鼻，68; 補冊 5, P. 45 55, (1965)

7) 切替一郎: 聴覚検查法. 第 2 版, P. 255 , 遊戯聴 力検查. (1974)

8）鳥山 稔：幼少児聴力検查法. 耳喉， $44 ；(10)$, 707,1972 .

(受付 50.2.4) 